\title{
Reading the Bible in the Middle Ages, edited by Jinty Nelson and Damien Kempf
}

London: Bloomsbury, 20I5 | 296 pages | ISBN: 978-I350-03628-4 (hardcover) \$I 22.00 | ISBN: 978-I-350-036284 (softcover) \$39.95 | ISBN: 978-I-474-2457I-5 (ebook) $\$ 35.05$

The genesis of the present volume was a dayconference at the University of Liverpool in $20 \mathrm{I}$ I. The resulting collection of eight articles offers a stimulating read for the biblical scholar who seeks to understand better how the Bible-with emphasis on the Old Testament-was being read, understood, and put to use in Europe in the Middle Ages. The essays all provide glimpses of various eras and geographical settings, ranging from the sixth century to the twelfth century CE, yet they form a coherent whole through their shared focus on the biblical texts.

After the Introduction where the editors offer a succinct and informative summary of the aims and objectives of the volume, the first article by Cornelia Linde, "Twelfth-Century Notions of the Canon of the Bible," demonstrates that, contrary to what is commonly assumed (also among biblical scholars), the canon of the Christian Bible was not yet completely fixed by the twelfth century CE. In particular, it was still an open question whether the Epistle to the Hebrews was authentic, as well as to what extent (from a Hebrew Bible perspective) deuterocanonical books such as the Prayer of Manasseh were to be considered canonical. Linde begins her study with a survey of views held by the Church Fathers vis-à-vis the Christian canon 
and highlights how different authorities counted the books differently, often attributing symbolic value to the resulting number. Whereas Jerome, for example, following the Jewish convention of treating I-2 Samuel etc. as one book, reached a total sum of 22 books of the Old Testament, a sum which also corresponds to the number of Hebrew letters, Augustine reached the double sum 44 due not only to a different counting of the books in the Old Testament but also by including (some of) the intertestamental books. Less variance could be observed regarding the books of the New Testament. Linde then discusses the views of two twelfth-century scholars. In the writing of the Saxon Hugh of St Victor (I096-I I 4I) who served in the Abbey of Saint Victor in Paris from I I 5 , the influence from Jerome is clear. Hugh divided the biblical books in such a way so that the structure of the Old Testament corresponded to that of the New Testament. He moreover added select writings of the Church Fathers as a separate section (patres) after the New Testament, not to be counted as on par with the biblical books but as a type of authoritative commentary. This inclusion raises the question as to whether Hugh considered these books to be canonical at least to some degree. Linde argues that Hugh saw the Bible as containing a nucleus of canonical writings, yet the canon itself was not limited to this core but open to additions. Turning to the English Robert of Melun (I IOO-I I67) who served towards the end of his life as bishop of Hereford, Linde shows that he was influenced by both Hugh of St Victor and Peter Abelard. He interacted with the aforementioned distinct views of Jerome and Augustine, yet ultimately seems to have preferred the latter's position. He further rejected his teacher Hugh's views on the patres because they interpreted not only the NT but also the OT; thus they could not be a part of the NT. He also attributed significance to the number of books—seven Catholic Epistles, ten Pauline Epistles, and four Gospels_-thus revealing that number symbolism formed an important part of canon discussions.

The second article, Gerda Heydemann's substantial contribution "The Orator as Exegete: Cassiodorus as a Reader of the Psalms," discusses the political use of the book of Psalms by Cassiodorus (485-585), a Roman statesman who served at the court of Theoderic the Great, king of the Ostrogoths, in Italy. In his retirement, he founded a monastery (Vivarium) and his writing became predominantly concerned with Christianity. Even though Cassiodorus left public life, however, he did not abandon his political interests. In her article, Heydemann highlights how Cassiodorus used the Psalter in his commentary (Expositio psalmorum) not only to evoke the early Christian history of Rome but also to speak to his contemporary audience. In particular, 
Expositio psalmorum features polemic against Arian Christians. This commentary is especially noteworthy because of its integration of biblical studies with classical arts, thus offering guidance not only in Christian theology but also in Roman political traditions. Cassiodorus read the Psalter as a collection of speeches, where the psalmist formed the ideal orator to be emulated. Cassiodorus developed the notion of Christian rhetoric, here understood as the means of persuasion, and highlighted the rhetorical means by which the biblical texts convey their message. For instance, he labelled the individual psalms according to their different types of rhetoric. To illustrate her point, Heydemann chooses, among other texts, Ps 73. Cassiodorus uses this lament psalm, attributed to Asaph, to showcase the manner in which Asaph pleaded with God to destroy Israel's enemies. In his commentary to the psalmtraditionally understood as speaking prophetically about the destruction of Jerusalem in $70 \mathrm{CE}$-Cassiodorus focuses not only on Asaph's rhetorical effort to defend Israel against its enemies (identified with the Romans of the first century CE), but also on how he lead the community in confession and repentance. In Cassiodorus's hands, Asaph becomes a political leader who can offer guidance to Cassiodorus contemporary Christian community.

The third article, "Lay Readers of the Bible in the Carolingian Ninth Century" by Jinty Nelson, explores how five select lay readers in ninth-century Europe, men and women alike, read and interpreted the Bible. At this time, due to greater availability of education offered by monasteries, literacy was increasing and actively promoted among the upper classes. As to texts, the Latin Vulgate was part of the fabric of conversation and culture. As a result, the Carolingian Empire began to see laymen and women who read and thought about the biblical texts on their own and who connected them with their own situation as a new "chosen people." God's command to Samuel to listen to the voice of the people (I Sam 8:7) constituted the impetus for laypeople to read the Bible. To illustrate this phenomenon, Nelson looks at the two letter-writers Einhard and Adalard, the lay historian Nithard, the lay poet Angelbert, and the laywoman Dhuoda who wrote a Handbook for her son. While Einhard focused on prayer and offered deeply personal reflections on the meaning of Jesus's victory on the cross, Adalard contemplated the force of demonic powers in the aftermath of the Battle of Fontenoy (84I) which culminated the Carolingian Civil War. Nithard, Charlemagne's grandson, uses the oracles of doom in Hosea and Ezekiel, as well as Paul's writing, in his Histories, to contrast the present dark days with the past glory of his grandfather's reign, while Angelbert's poetic description of the aforementioned bat- 
tle draws on the description of the Battle of Gilboa in 2 Sam I:2 I. Finally, Dhuoda quotes nearly every biblical book in an informed manner and with integrity as part of her instruction to her son.

The fourth article, "Jeremiah, Job, Terence and Paschasius Radbertus: Political Rhetoric and Biblical Authority in the Epitaphium Arsenii," by Mayke de Jong studies the references to the biblical characters of Jeremiah and Job in the writing of Paschasius, a monk and one-time abbot of Corbie. Paschasius lived during the tumultuous reign of Louis the Pious (8 I 4840 ) and was involved in the two failed revolts by the king's son to take their father's throne as he served as mediator between the three men. De Jong explores in particular Paschasius's work Epitaphium Arsenii where he describes (and also identifies with) Wala, who took a more active role in the aforementioned rebellions where he sided with the sons. De Jong begins with describing the relationship between Paschasius and Wala, the former being the latter's student and to a certain extent also his protégé who was meant to succeed him as abbot of Corbie but who like him was banished from court. She then discusses how Paschasius applied Ambrose's funeral oration for his brother (De excess fratris Satyri) as a literary framework for his work about Wala and how he modelled his depiction of his former teacher after the prophet Jeremiah: both spoke out against kings as part of their prophetic office, both sought to warn the people of the coming catastrophe, and both suffered as a result of their actions. This identification, moreover, gave Paschasius himself license to convey his own message as a fearless truthteller. Paschasius further emphasized the similarities between Wala and Job, as two men who suffered despite having sought to do justice, yet kept faith with God. He also highlighted the dialogical style of the book of Job which enabled Wala to respond to his accusers. Last but not least, de Jong also shows how Paschasius drew on the languages of Terence's comedies, even though their content had little relevance for his own topic, as they lent an authoritative note to his discourse. The article contains two useful appendices: the Latin text and an English translation of an illuminating part of the Epitaphium Arsenii which shows how Paschasius incorporated the biblical languages into his own writing in a fully integrated manner.

The fifth article, Henry Parkes's "Biblical Readings for the Night Office in Eleventh-Century Germany: Reconciling Theory and Practice," investigates the choice of biblical texts for the liturgy of the Night Office (vigiliis). As prescribed in the sixth-century Rule of St Benedict, books from both the Old and the New Testament should be read at this time, as well as select 
material from the writings of the Church Fathers. Through a careful study of three communities-Freising, St Gall, and Constance-Parkes highlights the difficulty in combining ideal theory with actual practice. The ideal was to read through the books of the Bible throughout the year in an orderly fashion befitting the liturgical year. This ideal was made difficult not only by the shifting date of Easter, resulting in different number of weeks between Easter and the other holidays from year to year, but also by local celebrations of Saints' Days. In practice, this meant that a given book should be read in four weeks in a given year, only to fit into merely three the following year. Lack of conformity was thus less a matter of laziness and more a matter of finding a practical way forward. In some cases, the solution was reading fewer books throughout the year than what was ideally prescribed, rather than reading a smaller section from all the required books. Parkes also highlights the role that music played, insofar as the choice of music by the cantor would dictate the choice of biblical lections, as well as the arrangement thereof. Parkes concludes with some reflection on how the variety and multiplicity of bible readings had less to do with institutional reforms and more to do with individuals who sought a compromise between ideal and local practices.

The sixth contribution, by Florian Hartmann, is called "'Quid nobis cum allegoria?' The Literal Reading of the Bible in the Era of the Investiture Conflict." It discusses the use of the Bible in the conflict between the Holy Roman Emperor King Henry IV (I050-I I06) and Pope Gregory VII. This was a time of multiple popes, church reform, and power struggle between Empire and Church, culminating not only in Henry's walk to Canossa but also in revolt and civil war. Gregory VII has gone down in history as the Pope who sought to cement the use of military violence in order to reach the goals of the Church. In this conflict, the Bible played an important role as both sides retorted to scripture to prove their point. Hartmann demonstrates that rather than using biblical passages which were interpreted symbolically and thus open to different interpretations, both sides used texts where the literal meaning supported their respective cause. For example, instead of referring to the potentially ambiguous text of Luke 22:38 which speaks of two swords, Gregory VII employed the more straightforward Jer 48:1o ("A curse on him who is lax in doing the LORD's work! A curse on him who keeps his sword from bloodshed!," NIB). Hartmann further argues that passages from the Hebrew Bible were more often employed in this struggle than material from the New Testament. He situates this appeal to the literal meaning of the bib- 
lical text within the wider movement in the eleventh century of preferring peshat, as evidenced in Christian Europe by Rashi and his grandson Rashbam. As the educated leaders of Empire and Church sought to convince the wider public who lacked any formal education of their views, arguments based on the biblical texts themselves rather than on more elaborate theological discussions or allegorical readings were more persuasive.

The seventh contribution, "Sybils, Tanners and Leper Kings: Taking Notes from and about the Bible in Twelfth-Century England" by Julie Barrau, explores the rarely studied so-called "miscellanies," i.e., manuscripts listing a series of short items. The manuscript under consideration is Corpus Christi College MS 288, written by an anonymous author in England in the third quarter of the twelfth century. It contains exegetical fragments relating to Kings (or Chronicles), Tobit, Judith, Nehemiah, Esther, Daniel, and Maccabees. Barrau characterizes the author's idiosyncratic style as a mixture of wide erudition and scholarly sloppiness. The latter trait, evident in his often careless use of his sources, combined with his lack of care for details, may stem from several circumstances. He may not have had direct access to his textual sources, instead relating to them from memory or, alternatively, from lecture notes. If the latter, the question arises whether his own notetaking is to blame or, as Barrau suggests, from his teachers' lack of precision. Barrau offers ample examples of the types of interpretations found in the manuscript. In many cases, we can trace the author's sources; in several other ones we cannot verify them. This inability, however, does not necessarily mean that our author invented the details; rather it is more likely that his sources have not been preserved to us. Our author is notably interested in the literal sense of the text, eschewing most symbolic readings. He also testifies to an interest in the historical situation presupposed in the text, as evidenced by his choice of texts. He is also interested in the geography of Jerusalem, as well as in other historical details.

The final article, Claire Weeda's "Violence, Control, Prophecy and Power in Twelfth-Century France and Germany," looks at the rhetoric of power in Christian German and French traditions before and during the early Crusades. Weeda highlights that different images are used for violence towards the "Other" on the inside, i.e., other (European) Christians, versus those that are employed for violence towards the "Other" on the outside, i.e., religious groups outside of Christendom. She begins by exploring how the Francs depicted their own violence towards one another as strong, yet characterized by self-discipline and justice, while the Germans were violent brutes who burst out in uncontrolled anger towards their fellow man. The Francs considered 
themselves to be God's chosen warriors who used controlled violence to further God's kingdom, whereas the German warriors in battle were "furious" and displayed madness. Yet when the Germans' fury was directed to the religious "Other" outside Christendom, they displayed courage and their strong physical endowments might even be extolled. Turning to German rhetoric, Weeda notes that they tended to depict themselves in eschatological terms as the ultimate rulers who would zealously restore law and order in the final era and bring about a just and ultimately peaceful kingdom. In contrast, they described the Francs as arrogant and insolent in their violence. In this way, the Germans and the Francs employed different yet similar types of rhetoric to define and also to defend their own violence, where ethnicity "offered some leeway and bargaining chips in order to stake claims to power within the traditions of politics and religion."

This is a very erudite and well-composed collection of articles which can be highly recommended.

Lena-Sofia Tiemeyer

University of Aberdeen 